\title{
Analysis of Vocational School Students' Ability in Conceptual Understanding
}

\author{
Riskana Br Sitepu ${ }^{1 *}$, Ani Rusilowati ${ }^{2}$, Bambang Subali ${ }^{3}$, Ahmad Sukron Khafifi ${ }^{4}$ \\ Physics Education Study Program, Postgraduate, Semarang State University ${ }^{1,2,3,4}$, \\ SMK Andalusia 1 Wonosobo* \\ riskanasitepu17@gmail.com¹, rusilowati@gmail.com², bambangfisika@mail.unnes.ac.id ${ }^{3}$, \\ sayasoekron@yahoo.com ${ }^{4}$
}

Received: December 10 $0^{\text {th }}, 2018$. Revised: March $5^{\text {th }}, 2019$. Accepted: March $8^{\text {th }}, 2019$

\begin{tabular}{ll}
\hline \hline Keywords : & ABSTRACT \\
Analysis; Rotational & The purpose of this study was to analyze the ability of \\
Dynamics; Conceptual & vocational students in understanding the concept of \\
Understanding & with 10 respondents consisting of high, medium and low \\
& categories. Instruments in this study used essay test with 6 \\
questions and interview. The results of this study showed \\
that students conceptual understanding in rotational \\
dynamics was low. Students were still having difficulties in \\
understanding the concept of Rotational Dynamics, namely \\
in determining angular velocity, inertia moment equation, \\
and solving equations. Then it is better to understand the \\
concept needs to be applied in the learning process. So it \\
can be concluded that conceptual understanding approach \\
needs to be applied in the learning process.
\end{tabular}

\section{INTRODUCTION}

Students' understanding in mastering physics concepts will affect the achievement of educational goals in the learning process. Mastery of concepts becomes very important for students because this is an indicator that students have fully understood what has been taught [1]. The ability to communicate is a simple and reliable way to identify key concepts and examine their epistemic justifications in the structured network [2]. Knowing is a metaphysical process where someone accepts a concept that is understood as true or valid. In this view, knowledge is characterized by how far someone accepts the validity of a concept. A person must have a logical or rational reason to be able to accept it [3]. Some representations of mathematical ideas can provide students with a better conceptual understanding. Well-chosen representations are very strong in conveying concepts. They can be effective at the beginner level or for students who consider themselves weak in mathematics and physics. They can also provide access to mathematical concepts for students who do not have operational expertise [4] [5] [6].

But in reality, there are still many difficulties found by students in dealing with physics related to conceptual understanding. Students face difficulties in applying mathematics in physics [7]. In addition, deeper difficulties are experienced in vocational students. Studying in vocational schools and workplaces are the two main components of vocational education. Students must develop 
professional competence by building a correlation between knowledge, skills and attitudes. Students struggle to apply algebra in physics, especially because they lack sufficient basic algebraic behavior and skills. They use ad hoc strategies instead of correct and systematic procedures based on rules that involve insight. This ad hoc strategy includes cross multiplication, numbering, and permutation strategies. They work only for basic formulas that contain several variables [8].

Further research is needed to analyze the vocational students' ability in understanding the concepts. The purpose of this study was to analyze the students' difficulties in understanding physics concepts in Rotational Dynamics. Classically, concept is the definition and abstraction of an event and a mental picture of an object. Conceptual understanding is a level in the cognitive domain that shows the ability to explain a simple relationship between facts and concepts. Concepts in physics are ideas about matter, experience, events of an object. In this study, the achievement of conceptual understanding indicators are interpreting, exemplinifing, classifying, summarizing, inferring, comparing, and explaining [9].

\section{METHOD}

This research is a qualitative research based on naturalistic understanding [10]. Qualitative research reveals a phenomenon that occurs and descriptive data collected. The subjects in this study were 10 students from SMK Andalusia 1 Wonosobo who were selected based on their ability level of high, medium and low. The data collecting technique is a written test, students are given 6 essay questions in conceptual understanding test about Rotational Dynamics. The students' steps in solving the problem are analyzed based on the scoring rubric on the ability to understand the concept.

\section{RESULTS AND DISCUSSIONS}

Descriptions test as many as 6 questions given to respondents. These questions are based on aspects of conceptual understanding. The distribution of questions is based on categories of conceptual understanding as presented in Table 1.

Table 1. Question distribution by category

\begin{tabular}{ccc}
\hline No & Aspect & Question Number \\
\hline 1. & Interpreting & 5 \\
2. & Exemplinifing & 2 \\
3. & Classifying & 3 \\
4. & Inferring & 4 \\
5. & Comparing & 6 \\
6. & Explaining & 1 \\
\hline
\end{tabular}

Table 2. Respondent's Answer Description

\begin{tabular}{ccccccc}
\hline $\begin{array}{c}\text { Question } \\
\text { Number }\end{array}$ & $\begin{array}{c}\text { Correct } \\
\text { Answer } \\
\text { with } \\
\text { Discussion }\end{array}$ & $\begin{array}{c}\text { Correct } \\
\text { Answer } \\
\text { without } \\
\text { Discussion }\end{array}$ & $\begin{array}{c}\text { Wrong } \\
\text { Answer } \\
\text { with } \\
\text { Discussion }\end{array}$ & $\begin{array}{c}\text { Wrong } \\
\text { Answer } \\
\text { without } \\
\text { Discussion }\end{array}$ & $\begin{array}{c}\text { Not } \\
\text { Answered }\end{array}$ & Total \\
\hline 1. & 0 & 0 & 6 & 3 & 1 & 10 \\
2. & 0 & 0 & 8 & 2 & 0 & 10 \\
3. & 1 & 1 & 4 & 3 & 1 & 10 \\
4. & 1 & 0 & 8 & 1 & 0 & 10 \\
5. & 6 & 1 & 3 & 0 & 0 & 10 \\
6. & 5 & 1 & 3 & 1 & 0 & 10 \\
\hline
\end{tabular}


Analysis of Vocational School Students' Ability in Conceptual Understanding Riskana Br Sitepu, Ani Rusilowati, Bambang Subali, Ahmad Sukron Khafifi

Table 3. Categories of Understanding of Rotational Dynamics Concept in Vocational Students

\begin{tabular}{ccc}
\hline No & Aspect & Category \\
\hline 1. & Interpreting & Fair \\
2. & Exemplinifing & Low \\
3. & Classifying & Low \\
4. & Inferring & Low \\
5. & Comparing & Low \\
6. & Explaining & Low \\
\hline
\end{tabular}

\section{Interpreting}

Question 5 about the angular velocity on the disk. In this question, many respondents have been able to interpret and understand the intended concept. So that the equation used by respondents to solve the problem has been answered correctly. But there are still respondents who are not thorough in calculations so the answer is wrong.

\section{Exemplinifing}

Question 2 about the size of two force moments with different rotating axes. There were four respondents who were quite good at answering, but not completely true. This is because respondents are inaccurate in understanding the questions in detail. So that in solving problems, respondents are trapped in the equation used to solve the problem.

\section{Classifying}

Question 3 about kinetic energy in solid balls that roll without slipping. To solve the question, thoroughness and focus on the explanation of moving balls rolling without slips and equations of solid balls. But from the respondent's answer, it was found that the respondents were not careful in answering questions. Judging from the respondent's answer, the respondent was wrong in the calculation to solve the problem.

\section{Inferring}

Question 4 about angular impulses with circular motion. From the results of the answers, it appears that the respondents did not understand the concept of the question. Respondents tend to focus on solving through equations or formulas without understanding the concept. Misunderstanding the concept, the final solution will be wrong. This is supported by the research conducted by Turşucu which shows that only $39 \%$ of students understand the concept of vectors [11].

\section{Comparing}

Question 6 about angular velocity at two inertia moments. From the respondent's answer, it can be seen that the respondents were able to compare and solve the equation used.

\section{Explaining}

Question 1 about the magnitude and direction of the force moment. It was seen that there were 3 respondents who had answered and explained but the final results were wrong. This is because the respondents did not understand the question.

Overall, based on the order from the highest level of understanding to the lowest level, found that there were no high category are fulfilled, for aspects of interpreting and comparing were in the fair category, and for aspects of exemplinifing, classifying, inferring and explaining in the low category. This means that there is a difference in the level of understanding between each aspect of understanding the Rotational Dynamics concept. So the results of this study are in line with Bloom's theory which suggests that aspects of interpreting and comparing levels are higher than the aspects of exemplinifing, classifying, inferring and explaining [12]. 
Based on the results of the test and interviews, it was seen that the respondents' ability to understand the rotational dynamics concepts was still very low. There are still many students who have not been able to understand the concept of each question tested. The same thing was also stated by Radiko et al. that the level of students' conceptual understanding is still in the fair category [13]. The low of students' conceptual understanding in explaining aspects is due to several factors, namely: a) Not all students are active in experimental and discussion activities. Students who are directly involved in experimental, discussions, or learning activities, will explore the concept more by making connections from separate pieces of information to become more detailed explanations [14][15], b) The question of conceptual understanding in the explaining aspect is in the difficult category. Praptiwi stated that student grades did not improve due to differences between the difficulty level of the questions and the level of students' understanding [16]. From the analysis results, the concept of understanding should be applied to the learning process. Teachers should use better learning methods to improve students' ability to understand concepts [17].

\section{CONCLUSION AND SUGGESTION}

Based on the results of tests and interviews given, it can be concluded that the vocational students' conceptual understanding is still low. Students are still not understand the concept of rotational dynamics, including determining angular velocity, the equations and solving moment of inertia. Then conceptual understanding approach needs to be applied in the learning process.

\section{REFERENCES}

[1] Hermann, R. S. (2012). Cognitive apartheid: on the manner in which high school students understand evolution without believing in evolution. Evolution: Education and Outreach, 5(4): 619-628.

[2] Hofer, S. I., Schumacher, R., \& Rubin, H. (2017). The test of basic Mechanics Conceptual Understanding (bMCU): using Rasch analysis to develop and evaluate an efficient multiple choice test on Newton's mechanics. International journal of STEM education, 4(1): 18.

[3] Koponen, I. T., \& Nousiainen, M. (2018). Concept networks of students' knowledge of relationships between physics concepts: finding key concepts and their epistemic support. Applied Network Science, 3(1): 14.

[4] Lee, J., \& Kim, J. B. (2018). Learning Assistant (LA) instead of Teaching Assistant (TA) in Korea?. Journal of the Korean Physical Society, 73(4): 414-421.

[5] Lidar, M., Danielsson, A. T., \& Berge, M. (2018). What Is Construed as Relevant Knowledge in Physics Teaching? Similarities and Differences in How Knowledge and Power Are Staged in Three Lower Secondary Classrooms. Research in science education: 1-20.

[6] Pateda, A. B., Kendek, Y., \& Saehana, S. (2015). Analisis Pemahaman Konsep Magnet Mahasiswa Calon Guru Fisika. Jurnal Pendidikan Fisika Tadulako (JPFT), 3(2): 13-17.

[7] Sabeel, U., \& Chandra, N. (2013, September). A Smart and Contemporary Home Security System using 802.15. 4 standard. In 2013 5th International Conference and Computational Intelligence and Communication Networks (pp. 374-379). IEEE.

[8] Sari, W. P., Suyanto, E., \& Suana, W. (2017). Analisis Pemahaman Konsep Vektor pada Siswa Sekolah Menengah Atas. Jurnal Ilmiah Pendidikan Fisika Al-BiRuNi, 6(2): 159-168.

[9] Sugiyono. (2008). Metode penelitian pendidikan:(pendekatan kuantitatif, kualitatif dan $R \& D$ ). Alfabeta.

[10] Sung, S. H. H., Shen, J., Jiang, S., \& Chen, G. (2017). Comparing the effects of dynamic computer visualization on undergraduate students' understanding of osmosis with randomized posttest-only control group design. Research and Practice in Technology Enhanced Learning, 12(1): 26. 
[11] Turşucu, S., Spandaw, J., \& de Vries, M. J. (2018). Search for Symbol Sense Behavior: Students in Upper Secondary Education Solving Algebraic Physics Problems. Research in Science Education: 1-27.

[12] Bloom, B. S., \& Krathwohl, D. R. (1956). Taxonomy of Educational Objectives: The Classification of Educational Goals; Handbook I: Cognitive Domain. NY: Longmans, Green

[13] Radiko, E., Kurniawan, Y., \& Muliyani, R. (2018). Identifikasi Pemahaman Konsep Siswa Pada Materi Zat dan Wujudnya. JIPF (Jurnal Ilmu Pendidikan Fisika), 3(2): 52-54.

[14] Rosdianto, H. (2017). Pengaruh Model Generative Learning Terhadap Hasil Belajar Ranah Kognitif Siswa Pada Materi Hukum Newton. Jurnal Pendidikan Fisika dan Keilmuan (JPFK), 3(2): 66-69.

[15] Rosdianto, H. (2017). Students`Conceptual Understanding through Generative Learning Model in Topic "Light". JPI (Jurnal Pendidikan Indonesia), 6(2): 259-262.

[16] Praptiwi, L., \& Handayani, L. (2012). Efektivitas model pembelajaran eksperimen inkuiri terbimbing berbantuan my own dictionary untuk meningkatkan penguasaan konsep dan unjuk kerja siswa SMP RSBI. Unnes Science Education Journal, 1(2): 86-95.

[17] Ahmadi, A., \& Supriyono, W. (2013). Psikologi Belajar. Jakarta: Rineka Cipta. 